Portland State University

PDXScholar

\title{
The Role of Marketing Education in Reactions to Advocacy Advertising
}

Tobin Carlberg

Portland State University

Follow this and additional works at: https://pdxscholar.library.pdx.edu/honorstheses

Part of the Advertising and Promotion Management Commons, Marketing Commons, Psychology Commons, and the Public Relations and Advertising Commons Let us know how access to this document benefits you.

\section{Recommended Citation}

Carlberg, Tobin, "The Role of Marketing Education in Reactions to Advocacy Advertising" (2020). University Honors Theses. Paper 863.

https://doi.org/10.15760/honors.884

This Thesis is brought to you for free and open access. It has been accepted for inclusion in University Honors Theses by an authorized administrator of PDXScholar. Please contact us if we can make this document more accessible: pdxscholar@pdx.edu. 
The Role of Marketing Education in Reactions to Advocacy Advertising

\section{by \\ Tobin Carlberg}
An undergraduate honors thesis submitted in partial fulfillment of the requirements for the degree of
Bachelor of Science
in
University Honors
and

Marketing \& Advertising

Thesis Advisor

Brandon Reich

Portland State University

2020 


\title{
The Role of Marketing Education in Reactions to Advocacy Advertising
}

Tobin Carlberg

Portland State University

\begin{abstract}
The present research aims to explore whether marketing education creates a positive or negative reaction towards advocacy advertising in general. To test this, consumers with varying levels of marketing education were either interviewed or surveyed to gauge their level of persuasion knowledge, advertising appreciation, and overall reactions to advocacy advertising. Thus, a combination of qualitative (interviews) and quantitative (survey) methods were employed. Interview results suggested that those with greater marketing education held more favorable attitudes toward advocacy advertising, and survey results illustrated a strong correlation between those with more marketing education and one's appreciation for advocacy advertising, which influenced positive reactions to the ads that were shown. However, there was no relationship between marketing education and one's persuasion knowledge, and persuasion knowledge in turn had no effect on reactions to the ads themselves. These findings help support the importance of marketing education at the college level, and its ability to create a critical understanding of artistic styles, and in acknowledgement of advertising's ability to shape cultural meaning.
\end{abstract}

Keywords: marketing education; advocacy advertising; advertising appreciation; advertising literacy; persuasion knowledge 


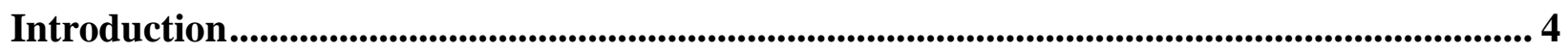

Conceptual Background .......................................................................................................................................... 5

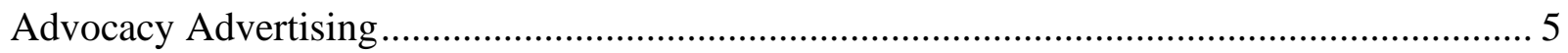

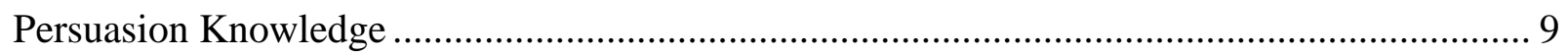

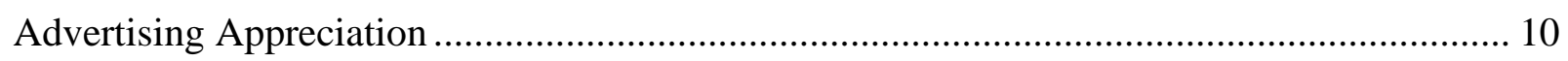

Hypothesis Development and Research Objectives ............................................................................. 12

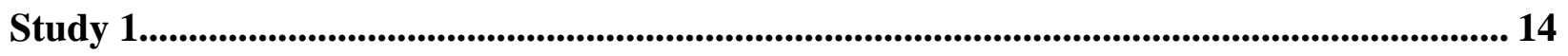

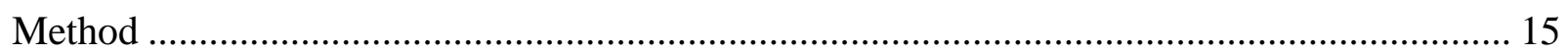

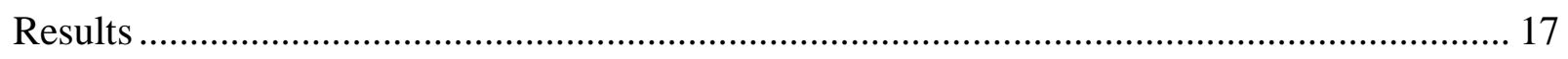

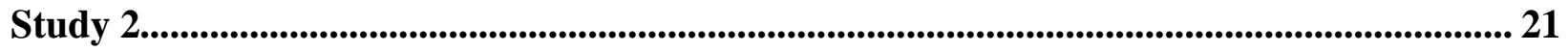

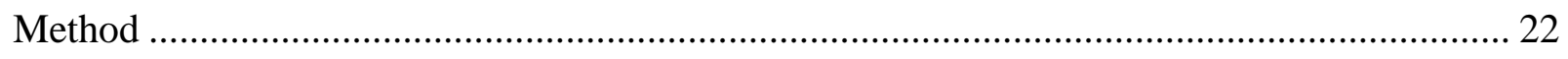

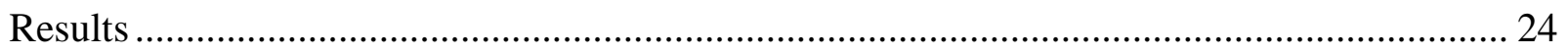

General Discussion........................................................................................................................................... 26

Theoretical and Practical Implications ................................................................................. 27

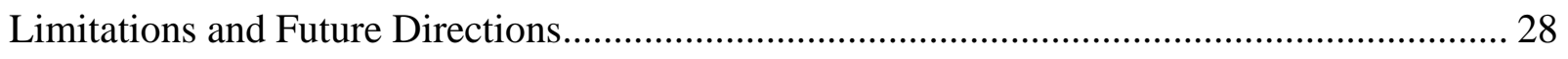

Acknowledgements ........................................................................................................................................... 30

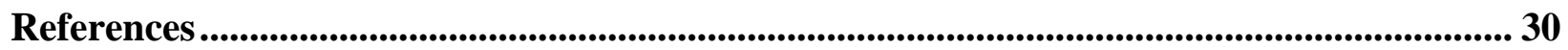




\section{Introduction}

Advocacy advertising has proven to be controversial, and has led to intense boycotts against brands across the nation (Halberstadt \& Schumacher, 2019). This form of advertising can be seen when a brand takes a stance on social, political, or environmental issues through their promotional campaigns (Cutler \& Muehling, 1989; Salmon, Reid, \& Pokrywczynski, 1985; Schumann, Hathcote, \& West, 1991; Wang \& Anderson, 2008). One notable example was Pepsi's ad in 2017, depicting Kendall Jenner at a protest. After its release, Pepsi faced scrutiny as consumers claimed they were capitalizing on the Black Lives Matter movement to generate profit (Solon, 2017). The controversy was not purely for political reasons. Rather, a majority of both liberals and conservatives on social media disliked the ad (Wagstaff, 2017). In light of this controversy and others like it, the current research will explore how consumers feel about advocacy advertising in general. More specifically, it examines an often-overlooked variable, marketing education, and its role in predicting consumer response to advocacy advertising.

As marketing education teaches about persuasive tactics, and since students will eventually become business professionals themselves, it is crucial that they are aware of the messages they receive in the media. As a result, consumers with higher levels of marketing education are becoming more aware of the intentions of marketers, leading to greater persuasion knowledge (Wright, Friestad, \& Boush, 2005) and thus more critical reactions to advocacy advertising (Boerman, van Reijmersdal, \& Neijens, 2012). On the other hand, marketing education may also enhance students' appreciation for advertising. An increase in advertising literacy can improve one's understanding of an ad in its style and cultural meaning (O'Donohoe \& Tynan, 1998; Ritson \& Elliott, 1995), and therefore create a more positive response to advocacy advertising. The present research, using a combination of interview and survey 
methodologies, will test the role of marketing education in explaining attitudes towards advocacy advertising, with a goal of clarifying the direction of the effect, whether that be positive or negative.

\section{Conceptual Background}

\section{Advocacy Advertising}

It is no secret that consumers distrust advertising. In a survey conducted by the American Association of Advertising Agencies, 1,005 people were questioned, and only four percent believed that the marketing industry "behaves with integrity" (Morrison, 2015). Marketing and advertising were ranked at the bottom of the list of industries that they believed practice integrity. Among this list, some of the industries that ranked higher included newspapers, pharmaceutical industries, the federal government and congress.

Since consumers show little confidence in advertising already, this distrust makes efforts difficult for companies to be perceived as genuine (Ellen, Webb, \& Mohr, 2006). This is especially true when they get involved in programs that focus on benefitting society, like Corporate Social Responsibility (CSR). CSR has been praised for being a favorable way to improve communities, increase customer loyalty, and create positive business reputations (Martínez \& Rodríguez del Bosque, 2013; Shaw, 2007; Stuebs \& Sun, 2010). This can be done through activities like philanthropy, environmental responsibility, cause-related marketing, and advocacy advertising (Babiak \& Trendafilova, 2011; Lii, Wu, \& Ding, 2013; Menon \& Kahn, 2003). However, consumers are often skeptical of CSR because it can seem like a money-making tactic rather than a genuinely altruistic effort (Ellen et. al, 2006).

Advocacy advertising is a specific form of CSR that has proven to be especially divisive. This is when a brand takes a stance on social, political, or environmental issues through their 
promotional campaigns (Cutler \& Muehling, 1989; Salmon, et. al, 1985; Schumann et. al, 1991; Wang \& Anderson, 2008). Because there are so many social problems in today's world (e.g., climate change, racial tensions, immigration, etc.), consumers are expecting brands to contribute to social change (Nielsen, 2017). However, as Taylor (2014) illustrates, it is very risky for companies to take sides on social issues. Making a claim in either direction risks alienating a significant portion of a company's audience.

As an example, Pepsi's campaign in 2017 took a stance on the Black Lives Matter movement. It portrayed a massive protest in the streets with people from all different nationalities, holding signs that promote peace and action. Just as the protesters and police were about to confront each other, celebrity Kendall Jenner walked through the crowd, handing one of the officers a Pepsi. As he takes the soda, everyone starts dancing and celebrating. After its release, it faced harsh criticism as consumers claimed Pepsi was capitalizing on the Black Lives Matter movement to generate profit (Solon, 2017).

Other examples of advocacy advertising include Nike's "Dream Crazy" campaign in 2018, which featured Colin Kaepernick, who voiced against racism and police brutality when he knelt during the National Anthem at one of his football games. Additionally, Gillette's 2019 campaign took a stance on toxic masculinity and sexual harassment following the \#MeToo movement. Both of these issues proved to be widely controversial and divisive, leading to intense boycotts against the brands (Dreyfuss, 2019; Halberstadt \& Schumacher, 2019).

However, these attacks against advocacy advertising go further than political controversy. Many consumers who may support the company's stance on the issue still have problems with the ad's portrayal. Halberstadt and Schumacher (2019) conducted focus groups to discuss the three campaigns (Nike, Gillette, and Pepsi), and found that consumer criticism extended beyond 
political ideology. For Gillette, while many thought it was important to illustrate this issue, some claimed that the idea of toxic masculinity was not properly represented, as it "communicates the generalization of all men being sexual harassers" (p. 41). They also saw Gillette's argument about toxic masculinity as illegitimate and hypocritical since they have portrayed gender stereotypes in previous ads. Thus, these moral judgements had much to do with how the brand aligns with the message itself.

In Nike's case, while some were inspired by the ad and its message, other consumers questioned their motives to use an issue like racism, because they did not see Nike doing enough to support social change outside of the campaign (Halberstadt \& Schumacher, 2019). Some felt their ad was inauthentic because the issue was not part of Nike's core business, and instead was being used as an opportunity for marketing hype. In addition, with Nike's choice to make Colin Kaepernick their spokesperson, many thought using the line "Believe in something, even if it means sacrificing everything" (p. 40) was fitting, given how risky it was to kneel during the national anthem, thereby losing his opportunity to play in the NFL. Meanwhile, others felt that the use of the phrase "sacrificing" would be better suited to a military veteran than a professional athlete. Similarly, the critics against Pepsi's ad had a difficult time connecting Kendall Jenner with the issue, wondering whether a white American model born into a rich family has any credibility in a struggle facing marginalized identities or in social movements in general.

These findings suggest that consumer skepticism towards advocacy advertising is not just grounded in one's political affiliations, but in consumers' beliefs about advocacy advertising in general. Therefore, it seems that political ideology cannot entirely explain differing reactions to advocacy advertising. Yet, prior research (Burgoon, Pfau, \& Birk, 1995; Haggard, Yao, \& Cai, 2014; Haley, 1996) has emphasized the role of political ideology in this domain. In contrast, the 
current study examines an additional factor, marketing education, that goes beyond politics yet still may influence reactions to advocacy advertising.

Hoeffler and Keller (2002) state that the "power of a brand is in what resides in the minds of customers" (p. 79). The reputation of a brand affects their corporate, product and brand evaluations. Even if there are negative responses on just one part of the business, it can carry over to other parts of the brand, even to the product itself (Klein \& Dawar, 2004). Additionally, if a company's values do not align with the cause, a campaign will appear "out of character" (Skarmeas \& Leonidou, 2013, p. 1833). It makes the brand look like they are misleading consumers just to increase sales, thus illustrating their agenda as self-centered and egoistic (Ellen et. al, 2006).

Consumers rely on three components to judge advocacy advertising: the organization, the issue, and the self (Haley, 1996). The "organization" refers to how the brand aligns with the issue, the "issue" explains if the brand properly represents a specific topic, and the "self" determines if an issue aligns with a consumer's own morals. In other words, a campaign's message will appear more credible when it aligns with the consumer's moral beliefs (Elliott \& Wattanasuwan, 1998), while staying true to a brand's values, and their authentic voice. That is why it is important for brands, if they decide to stand for something, to be genuinely interested in promoting social issues.

Halberstadt and Schumacher (2019) created evaluation criteria for judging advocacy advertisements. Some of these include having a plan to implement social change, a legitimate moral position that aligns with the brand's values and hiring spokespeople with a clear connection to the company. Brands need to understand that they have an impact on social change, and the way they present a certain issue can frame social norms, which lead to "changes 
in the perception of political actors and the system as a whole" (p. 68). Therefore, due to its enormous influence, advocacy advertising has to be handled responsibly.

It is important to understand the role marketing education plays in developing critical responses to these types of messages. From a theoretical perspective, marketing education may serve as an important yet unexplored predictor of consumer reactions to advocacy advertising, beyond political ideology. On a more practical level, marketing students need to be aware of when companies are using social issues, and if they are doing so genuinely. Since they will become business professionals themselves, these same students will shape the future of advertising.

\section{Persuasion Knowledge}

When marketers attempt to influence consumers through persuasion tactics, consumers may develop a skill to process persuasive messages. This is called "persuasion knowledge" (Friestad \& Wright, 1994). Persuasion knowledge refers to one's ability to assess the credibility of the advertiser, while acknowledging the goals and tactics of the persuasion attempt. In other words, it is the level of understanding one has to interpret messages, recognize messages as persuasive attempts, and cope with these persuasion attempts across different media.

According to the Persuasion Knowledge Model (Friestad \& Wright, 1994), it is an “experience-based" (p. 7) process that is shaped through a combination of one's peers (family, friends, mentors), efforts in the media, and the education system. Individuals with higher persuasion knowledge can separate their emotional reactions to an ad and focus on the information about the product or service itself. In addition, they are able to critically understand the goals and tactics of sales presentations as they see them. This creates the change-of-meaning 
principle, where the content is perceived differently after one acknowledges the persuasive tactics of the ad (Friestad \& Wright, 1994; Wright et. al, 2005).

In general, the Persuasion Knowledge Model has shown that consumers are more critical when they sense marketers are trying to persuade them (Buell \& Norton, 2011). Given the notion that most consumers are skeptical of advertising anyway (Dahlén, 2005), it is no surprise that accessing one's persuasion knowledge will raise cognitive defenses (Russell, 2002), which will ultimately lead a consumer to "question the credibility" of the advertising message (Xu \& Wyer Jr., 2010). The work of Henrie and Taylor (2009) found that Millennials with high persuasion knowledge were more likely to develop negative reactions in sales promotions. Furthermore, even though there is evidence that supports persuasion knowledge as a contributor for greater appreciation of many advertising formats (Tutaj \& van Reijmersdal, 2012), higher persuasion knowledge generally leads to more critical and resistant attitudes (Boerman et. al, 2012).

These critical attitudes help explain the controversial response to advocacy advertising. Consumers who have high amounts of persuasion knowledge may watch an ad containing a social issue, and see beneath the emotional resonance, that this company is ultimately trying to sell them a product. One of the most difficult parts about advocacy advertising is that a company has to balance their economic interests with the needs of society (Ellen et. al, 2006).

\section{Advertising Appreciation}

As Friestad and Wright (1994) specify, persuasion knowledge is shaped by the media, advertising and marketing experts, and by teaching school children in the classroom. The work of Brucks, Armstrong, and Goldberg (1988) suggests it is important for children to obtain knowledge about persuasive tactics in order for them to cope with advertising messages. More specifically, crucial learning about advertising tactics happen between "their toddler years and 
the time they graduate from high school" (Wright et al. 2005, p. 222). Thus, most consumers have a strong understanding of how advertising works by the time they reach college. However, a person's level of experience with advertising (i.e., advertising literacy) can differ based on their exposure to and knowledge about advertising (Malmelin, 2010).

Advertising literacy is a similar concept to persuasion knowledge, but in a broader sense. It refers to a set of skills that help consumers interpret and understand advertising's various techniques and strategies (O’Donohoe \& Tynan, 1998). Through observation and recognition, one can point out important details that a casual viewer cannot (Nava \& Nava, 1990). Someone with high advertising literacy can look at a piece of advertising and find new meaning by interpreting its verbal and non-verbal cues with a "capacity for highly metaphorical, imaginative thinking" (Scott, 1994, p. 475). As mentioned before, with more exposure to commercial messages, one will have more literacy skills to cope with advertising (Malmelin, 2010).

Contrary to the persuasion knowledge framework, those with high advertising literacy may react to advertising positively because they appreciate it more. A study by O'Donohoe and Tynan (1998) found that individuals with high advertising literacy can "adopt different roles in relation to advertising" (p. 480). For example, participants displayed a "sophisticated appreciation of advertising conventions, styles and trends" (p. 473). Thus, one's advertising literacy can translate into a greater appreciation for an ad. This type of appreciation is seen in the intricacies of how the ad is made, as a form of art. From the words of the famous advertising creative director William Bernbach, "Advertising is fundamentally persuasion and persuasion happens to be not a science, but an art” (Ignatius, 2013). Similarly, Ritson and Elliott (1995) showed that advertising literacy can help shape cultural meaning, which allows consumers to appreciate ads more by interpreting them in unique ways. This shared cultural meaning also 
allows us to communicate and share ideas about ads from both a critical and appreciative perspective.

Overall, existing research suggests that a more extensive marketing education may create both greater persuasion knowledge and appreciation for advertising (through advertising literacy). Persuasion knowledge is likely to generate negative reactions to advocacy advertising while one's appreciation may generate positive reactions. The role of marketing education in predicting response to advocacy advertising therefore remains an open question.

\section{Hypothesis Development and Research Objectives}

The purpose of this research is to test whether consumers' marketing education predicts their response to advocacy advertising, and if so, whether the relationship is negative (through persuasion knowledge) or positive (through advertising appreciation). Thus, the present research helps answer this fundamental question: does studying marketing lead to more or less favorable reactions to advocacy advertising?

A mixed methodology, involving both qualitative (interviews) and quantitative (survey) instruments, was employed. In both instances, sampling was conducted to purposefully capture a broad range of levels in marketing education among participants. As the main outcome variable, the survey portion measured respondents' overall reactions to one of several prominent advocacy ads in terms of how the issue is presented in the ad, and how authentic it feels. As potential mediating variables, persuasion knowledge and advertising appreciation were also measured in the survey portion. The goal is to add to the work of Wright et. al (2005) in the development of persuasion knowledge in young adults, and in the exploration of advocacy advertising in the context of persuasion knowledge. A further objective is to build on the work of Ritson and Elliott 
(1995) and O'Donohoe and Tynan (1998) to understand how one's advertising literacy might enhance positive reactions to advertising through appreciation.

From the literature reviewed above, one's level of marketing education should impact their reaction to advocacy advertising. However, whether the reactions are more positive or negative is still unclear. Therefore, the hypothesis has two parts, which predict two potential outcomes. Firstly, with reference to potential negative reactions, higher persuasion knowledge generally leads to more critical and resistant attitudes (Boerman et. al, 2012). H1a reflects the potential negative response through enhanced persuasion knowledge:

H1a: More marketing education will enhance one's persuasion knowledge, shaping a negative and critical reaction towards advocacy advertising.

On the other hand, as described in the background section above, marketing education could also enhance students' appreciation for advertising. Because an increase in advertising literacy can improve one's appreciation for an ad in its style and cultural meaning (O'Donohoe \& Tynan, 1998; Ritson \& Elliott, 1995), H1b suggests a positive relationship:

H1b: More marketing education will create a greater appreciation for advertising in general, leading to a positive reaction towards advocacy advertising.

The reason for these competing hypotheses is also due to the controversial nature of advocacy advertising (Halberstadt \& Schumacher, 2019), suggesting that there is much ambiguity in how participants will potentially respond (see Figure 1 below for a full model of the competing hypotheses). 
Figure 1. Full model illustrating the competing hypotheses.

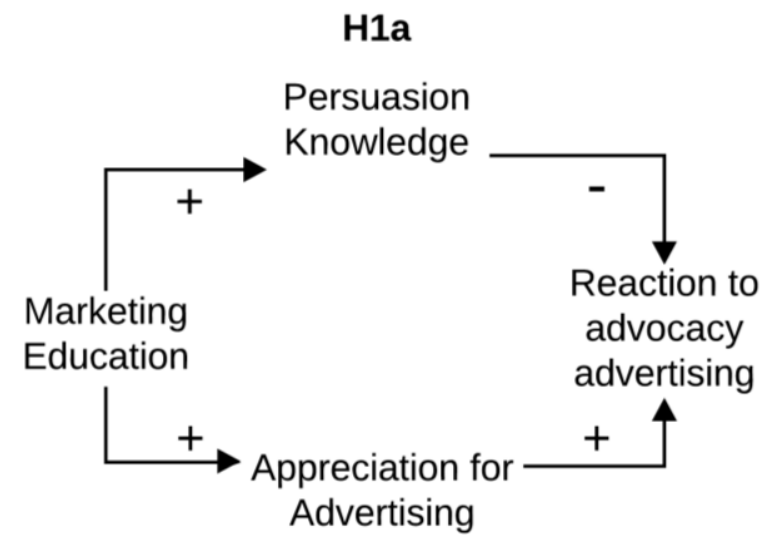

H1b

\section{Study 1}

As an initial exploration, open-ended questions were utilized in an interview format to conduct an in-depth analysis of how students react to advocacy advertising. Data were first collected through interviews using a convenience sample. The sample consisted of three marketing students and three non-marketing students $\left(M_{\mathrm{age}}=23.83 ; 50 \%\right.$ Female $)$ from Portland State University (PSU). There was one sophomore, one junior, and four seniors. The three nonmarketing students came from business management, finance and public health.

It was important to gather data from students with a variety of educational backgrounds, mainly to determine whether their thoughts on advocacy advertising differed based on their field of study. The interviews were transcribed, and responses were coded for common themes using an iterative approach (Glaser \& Strauss, 1967). The aim was to explore whether respondents felt more appreciative or skeptical towards prominent examples of advocacy advertising, and if this bore any relationship to their marketing education. 


\section{Method}

Before the interviews took place, each participant was asked to watch three videos- the Nike, Pepsi and Gillette ads described above. These ads were used due to their high popularity and controversy (Halberstadt \& Schumacher, 2019), which made them more recognizable to the respondents, and representative of advocacy advertisements in general. After participants finished watching all three ads, they were asked a series of open-ended questions (see Table 1) in a semi-structured format. These questions examined their thoughts on advertising in general, if any of the ads they saw felt genuine or fake, their thoughts about social issues in advertising, if companies should take sides on these issues, and if they think advocacy advertising creates cultural meaning. Lastly, they were asked about their political ideology, age, gender, and how many marketing and advertising classes they have taken. Asking about political ideology was mainly to test the idea that marketing education has an effect on reactions over and above the effect of political orientation.

The questions are reflective of the work from Haley (1996), and how consumers morally judge advocacy advertising: through the organization, the issue, and the self. It was important to see if respondents believed the brand was aligned with the issue, and if the issue was properly represented. It was also helpful to borrow from Halberstadt and Schumaker's (2019) evaluation criteria for judging advocacy advertising. These main components included making sure brands hire spokespeople that reflect their values, and that companies are implementing social change initiatives when they promote social issues. Another heavily utilized concept was motive attribution, which was used to tell whether respondents felt the company's choice to incorporate social issues were more self-centered or in the best interest of the consumer and society as a whole (Ellen et. al, 2006). Lastly, questions were used to reflect the ideas of Ritson and Elliott 
(1995), to see if respondents felt advertising creates cultural meaning, and if advertising should be appreciated as a form of entertainment (O’Donohoe and Tynan, 1998).

Table 1. Interview protocol.

\section{Interview Questions}

What are your thoughts on advertising in general?

What role should advertising play in entertaining people?

Name an example of an ad you saw as genuine, and what about it made you enjoy it? It can be the ads I showed you or any ad you can think of.

Name an example of an ad that felt manufactured and fake. Why did it make you feel that way? It can be the ads I showed you or any ad you can think of.

When you see an ad promoting a social cause, do you think the company truly believes in it?

What role should brands play in promoting social issues?

More specifically, what role should brands play in taking sides on these issues?

Why do you think this has become a common practice?

How should companies balance their social responsibilities (to the community and environment) with their financial expectations to make money?

Do you think promoting social issues adds more cultural meaning, and thus create an impact for change?

Would you consider yourself a very skeptical person when it comes to advertising?

How has your perspective of marketing and advertising changed since you first started at PSU? (only for marketing students) 


\section{Results}

The length of the interviews was drastically different between marketing students to nonmarketing students. The average time spent on interviews with marketing students was 57.7 minutes, while the average time for non-marketing students was 22.3 minutes. This is a result of how thorough and detailed the marketing students' responses were. Instead of solely focusing on their personal reactions to the ad, they were attempting to find the intentions of the marketer. For example, when discussing how they felt about each ad, a marketing major said the following:

"Gillette's ad felt the most genuine since they weren't using their product as a solution to the issue. Gillette's purpose wasn't to sell products, it was to spread a message. Pepsi is the complete opposite. That ad was distasteful, and not as impactful as they wanted it to be. I see what they were trying to do, I really could. But, given the context of when that came out, of when there were tons of videos of police brutality and violence against black men and women, it did not hit well at all. If you want to spread a message about police brutality, Pepsi is probably not the best company to do that. There's a lot of companies that do it well by saying that their product won't necessarily fix the issue, but that they support progress. These brands that have such intense market share, they think they can get away with it" (Marketing major 1 - took nine marketing classes and one advertising class).

Illustrated in this response, the marketing student described the intentions of the marketer, which reflects their persuasion knowledge (Friestad \& Wright, 1994; Wright et. al, 2005). More specifically, they were able to explain why they liked and disliked certain ads based on the strategies they used. As mentioned, they enjoyed Gillette's ad because they were not using their product "as a solution to the issue". Additionally, the respondent contextualizes why it is a sensitive matter for Pepsi to allude to this controversial issue, given the significant racial tensions (Solon, 2017), further exemplifying the lack of connection between Pepsi and promoting social movements. They are clearly separating their emotional reactions to the ad, while describing their perception of the company's motives. The respondent's ability to question the credibility of Pepsi through critical eyes also reflects the work of Xu and Wyer Jr. (2010). Meanwhile, nonmarketing majors tended to focus more on their emotional reactions: 
"I really liked the Gillette ad. If you take offense to a commercial telling you if you see your son being a bully or macho man, then that's what he's going to be like when he grows up, you're clearly doing something wrong. You shouldn't be offended by the idea that the children of today need to be taught how to behave appropriately. If you take pride in the way you raise your children, it shouldn't have been a big deal to have this out there" (Public health major- took zero marketing classes).

While this is a very in-depth response, there is not much of a focus on the ad's stylistic choices, nor its persuasive elements. It is more of a description of public perception. There is no reference to Gillette's selling tactics, which probably reflects the respondent's positive reaction. One of the main components of persuasion knowledge is in one's ability to separate emotional responses from the information presented. Consumers with less persuasion knowledge tend to go straight towards their initial, emotional reactions, which can be reflected here (Friestad \& Wright, 1994; Wright et. al, 2005). This idea of separating emotional reactions to the message's intent can be further exemplified in this response:

\footnotetext{
"The things said in the advertisement, Nike stands with those ideals very firmly. In Nike's daily activities as a company, with their employees, those things are all consistent. The two companies went at their issue in two different ways, but the Nike ad felt a little more genuine than Gillette. Especially since Nike wasn't actively supporting Kaepernick's cause but alluding to it. Gillette was showing a great social cause that's happening and is in the process of happening. They definitely are in a place to do that since they are a men's razor. Where they missed was the fact that they showed where we are now, as men, and that we are so far from that. And I feel that it's attacking fathers, and it's almost saying that parenting is the problem when it comes to toxic masculinity. In particular, dads might feel attacked because they are telling them they are being a bad father if they're not doing these things. It wasn't the issue, but the execution of the issue itself" (Marketing major 2 - took nine marketing classes).
}

The important takeaway is that this respondent explicitly separates the company's message from the social cause. Even when they agree with the social issue itself, that does not mean they can appreciate its execution. That distinction is crucial because it illustrates a strong use of persuasion knowledge. In particular, it is the way the respondent was able to decipher the emotional appeals from the social issue in order to find the effectiveness of the persuasion attempt (Friestad \& Wright, 1994). In this case, it created a negative and more critical reaction towards Gillette, reflecting their persuasion knowledge. 
However, the marketing students also demonstrated more appreciation than nonmarketing students for these advertising messages, since they believed it had a significant influence over consumers and society as a whole. For example, one marketing student argues that there is power in promoting social issues:

"These types of campaigns take a lot of research and execution. If it's really powerful and impactful, it can do huge things for a company and society. And if it's a bad one, it can do huge things too, but in a completely opposite direction. Before I took classes, I don't think I realized the impact marketing and advertising had on a company. That may be a biased opinion, because I'm passionate about it. But I do feel a great appreciation for advertising that's well-done" (Marketing major 2 - took nine marketing classes).

This respondent displays a high amount of appreciation, especially in their acknowledgement of marketing campaigns and their processes. This appreciation reflects the work of O'Donohoe and Tynan (1998) in one's ability to recognize the intricacies of how an ad is made, in its various styles and executions. It also illustrates Ritson and Elliott's (1995) work, in the way consumers see ads as catalysts for change. Conversely, when asked about its impact for change, a non-marketing student had less faith in the effectiveness of advocacy advertising:

"I think it does well with their company, but outside of that, I don't think so. It's definitely an internal thing, but not necessarily to the customer. I don't think it would reach the customer because they aren't really part of that movement. If you're not part of that culture, it's not the same" (Finance major- took one marketing class).

It appears that this student, along with other non-marketing students who were interviewed, had less confidence in advocacy advertising. A possible explanation could be that individuals who are less involved in the field do not see in its effectiveness. As another nonmarketing student put it, advertisers use social issues to make companies look more responsible than they actually are, and that it is "more for profit and attention".

After asking them if they felt more positive or negative towards advocacy advertising in general, the non-marketing students felt either negative or indifferent. Meanwhile, the marketing students unanimously all said they felt positive towards advocacy advertising. However, with 
this feeling of positivity about social issues, they were still wary about the marketer's intentions.

This comment sums up the dichotic nature of their perspectives:

\footnotetext{
"Generally, I think my initial reaction is positive, at least when the ad is good. Despite being an empty gesture since companies ultimately do it to only make more profit, it at least puts the issues out there, even if it's for a moment. Ironically, in the long run, especially with this crazy lockdown (COVID-19

Pandemic), it'll force companies to be careful. As society is once again reexamining itself, if companies decide to come out with ads related to a social issue, it can cause consumers to hold them to a new standard" (Marketing major 3 - took eight marketing classes and seven advertising classes).
}

This response helps illustrate that even though marketing students can feel positive about the impacts of advocacy advertising, their view of marketers and their intentions are still critical. This double-sided perception can be illustrated in the work of Williams and Aaker (2002), who state consumers can simultaneously hold positive and negative feelings about advertising when they see ads with "mixed emotional appeals" (p. 639).

In terms of political ideology, most of the respondents tended to identify as moderate, but were leaning towards liberal. Even within similar ideologies, they had various opinions about the ads themselves. Some saw Nike's ad as genuine and inspiring, while others claimed it twisted Kaepernick's message for publicity. Gillette's ad was perceived as an important message to some, and a poorly executed campaign for others. Pepsi's ad was universally disliked.

Although they displayed diverse opinions about each ad, marketing students had similar criteria for judging advocacy advertising. The common theme was that when social issues were presented well, the message was more powerful, which in turn allows the ad to spark important conversations for society. On the other hand, if an ad was poorly executed, marketing students were able see through their corporate agendas. In other words, they were able to enhance their persuasion knowledge when they felt the company's intentions were self-centered and found appreciation when the ads were done well. In reference to their marketing education, this comment sums up the findings perfectly: 


\begin{abstract}
"To be appreciative you have to be critical. To appreciate something, you have to appreciate that it's done well and that it means something. To know those things, you have to be critical of it too, and look at it from an objective lense from where it went right and went wrong. I don't think they are mutually exclusive; one definitely ties into another. Marketing education has made me more analytical, but it has made me more appreciative" (Marketing major 2- took nine marketing classes).
\end{abstract}

Regarding the hypotheses, these preliminary results are more consistent with H1b than H1a. Even though marketing (vs. non-marketing) students displayed greater persuasion knowledge through critical comments towards certain ads, their overall reaction was more positive. As predicted by H1b, each marketing student's positive reactions seemed driven by a greater appreciation towards advocacy advertising in general. They appeared to have respect for brands who were willing to take risks and stand up for social issues, even though they understood that the ultimate goal was to sell something. The marketing (vs. non-marketing) students were especially proud that they could differentiate between a genuinely-motivated ad versus an egoistically-motivated one. Because they have studied advertising thoroughly enough to know what a good ad campaign looks like, they could determine whether the company seemed to care, or if they were just in it for profit. Additionally, since they recognized how much work it takes to create a strong campaign, they really seemed to value a creative ad that could promote a compelling message. If it was done extremely well, these marketing students believed in its ability to create change in some way.

\title{
Study 2
}

To examine more closely consumers' reactions towards advocacy advertising, while measuring persuasion knowledge and advertising appreciation on a broader scale, a survey was sent to students at PSU through an undergraduate participant pool. This served to further test the model shown in Figure 1 above using a quantitative approach. The participant pool allows students across the business school to receive extra credit for completing a series of surveys (including the present survey). The sample included responses from 236 participants. Six of 
these participants were excluded from the analyses for failing an attention check question, leaving a sample of 230 participants $\left(M_{\text {age }}=26.62 ; 57 \%\right.$ Female $)$.

Participants also indicated their political ideology $(1=$ extremely liberal, $9=$ extremely conservative), and the sample leaned liberal but with substantial variation $(M=4.21, \mathrm{SD}=1.59)$. In regard to classes, PSU's minimum requirement for marketing and advertising majors is that they complete at least seven courses. However, only $25 \%$ of the respondents took seven or more marketing and advertising classes. This means that a significant portion of the respondents were most likely new marketing majors, or students from other majors. This may also be due to the fact that $57 \%$ of participants who took the survey were first or second-year students. Typically, most students will not start their upper division marketing classes until their third and fourth years in school. Nonetheless, the sample represented a variety of business disciplines and therefore provided a range of marketing education levels (Marketing Classes $=3.79, \mathrm{SD}=3.44)$.

\section{Method}

Participants were randomly assigned to view one of the three advocacy ads (Nike, Pepsi, Gillette), and provided their reaction towards the ad they saw in terms of how genuine they felt the company's motives for creating the ad were. In particular, items used to measure these inferences of genuine motives were adapted from Ellen et. al (2006) and served as the core dependent variable. The questions were scaled from 1 (strongly disagree) to 9 (strongly agree; see Table 2 for scale items). Responses were coded such that higher scores indicated more positive reactions toward the ad (in terms of inferences of genuine motives). Next, participants' general persuasion knowledge was measured through the Consumer Self-Confidence Scale (Bearden, Hardesty, \& Rose, 2001), which is designed to reflect the respondent's confidence in their ability to cope with persuasion tactics in marketing and advertising. A question was also 
gathered from Buijzen (2007) to determine if consumers felt there was deception in advertising. Higher scores indicated greater persuasion knowledge.

Appreciation for advertising was measured using a scale from Mehta (2000) that assessed opinions about advertising in its "informational value, trustworthiness, and impact on product quality" (p. 68). Questions were added to reflect the idea that a greater appreciation for advertising means seeing it as a form of artistic expression, and as something to be enjoyed (O’Donohoe \& Tynan, 1998; Ritson \& Elliott, 1995). Higher scores indicated greater appreciation for advertising in general. Lastly, the survey ended with questions about political ideology, age, academic rank, gender, and the number of marketing and advertising classes they have taken. Standard multivariate analyses (ANOVA, mediation tests, and regression) were used to test the hypotheses. 
Table 2. Survey questions to test reaction towards advocacy advertising, and to measure respondent's overall level of persuasion knowledge and advertising appreciation.

\begin{tabular}{|c|c|c|c|}
\hline & $\begin{array}{l}\text { Reactions to the ad } \\
\text { (Genuine Scale) }\end{array}$ & $\begin{array}{l}\text { Persuasion Knowledge } \\
\text { Scale }\end{array}$ & $\begin{array}{l}\text { Advertising Appreciation } \\
\text { Scale }\end{array}$ \\
\hline \multirow{5}{*}{ Scale Items } & $\begin{array}{l}\text { The brand believes in } \\
\text { this cause. }\end{array}$ & $\begin{array}{l}\text { I know when an offer is } \\
\text { too good to be true. }\end{array}$ & $\begin{array}{l}\text { I find enjoyment in } \\
\text { advertising. }\end{array}$ \\
\hline & $\begin{array}{l}\text { The brand feels morally } \\
\text { obligated to help. }\end{array}$ & $\begin{array}{l}\text { I can tell when an offer has } \\
\text { strings attached. }\end{array}$ & $\begin{array}{l}\text { I see advertising as a } \\
\text { form of artistic expression. }\end{array}$ \\
\hline & $\begin{array}{l}\text { The brand has a long- } \\
\text { term interest in the } \\
\text { community. }\end{array}$ & $\begin{array}{l}\text { I know when a marketer is } \\
\text { pressuring me to buy. }\end{array}$ & $\begin{array}{l}\text { I like to look at } \\
\text { advertising. }\end{array}$ \\
\hline & $\begin{array}{l}\text { The brand uses the } \\
\text { proper actors and } \\
\text { spokespeople to } \\
\text { communicate this issue. }\end{array}$ & $\begin{array}{l}\text { For marketers, persuading } \\
\text { is more important than } \\
\text { entertaining. }\end{array}$ & $\begin{array}{l}\text { Brands that are advertised } \\
\text { are better in quality than } \\
\text { brands that are not } \\
\text { advertised. }\end{array}$ \\
\hline & & $\begin{array}{l}\text { I think that commercials } \\
\text { use special tricks to make } \\
\text { products and services look } \\
\text { better than they are. }\end{array}$ & $\begin{array}{l}\text { Advertising helps keep me } \\
\text { up-to-date about products } \\
\text { and services that I need or } \\
\text { would like to have. }\end{array}$ \\
\hline Reliability & .91 & .70 & .82 \\
\hline
\end{tabular}

\section{Results}

Since the respondents were only shown one out of three ads, there was a possibility that the way they answered the survey could be affected by the particular video they saw. To test this, a series of ANOVAs were first used treating the video factor as the predictor and each of the three scales as the dependent variables (advertising appreciation, persuasion knowledge and the genuine scale). Results showed that respondents' persuasion knowledge and advertising 
appreciation were not affected by which video they saw (both $p$ s $>.14$ ). However, there was variation between videos in participants' perceptions of how genuine each ad was, since the means scores varied significantly. In particular, Pepsi's ad $(M=4.26, \mathrm{SD}=2.05)$ produced significantly less favorable reactions than the Nike $(M=7.40, \mathrm{SD}=1.47)$ and Gillette ad $(M=$ $6.98, \mathrm{SD}=1.56, F=75.62, p<.001)$. This means that their reactions differed based on the video they watched (see Figure 2 below for average scores based on the genuine scale). The video factor was therefore controlled as a covariate in the subsequent analyses.

Figure 2. Average scores for the genuine scale for each video condition.

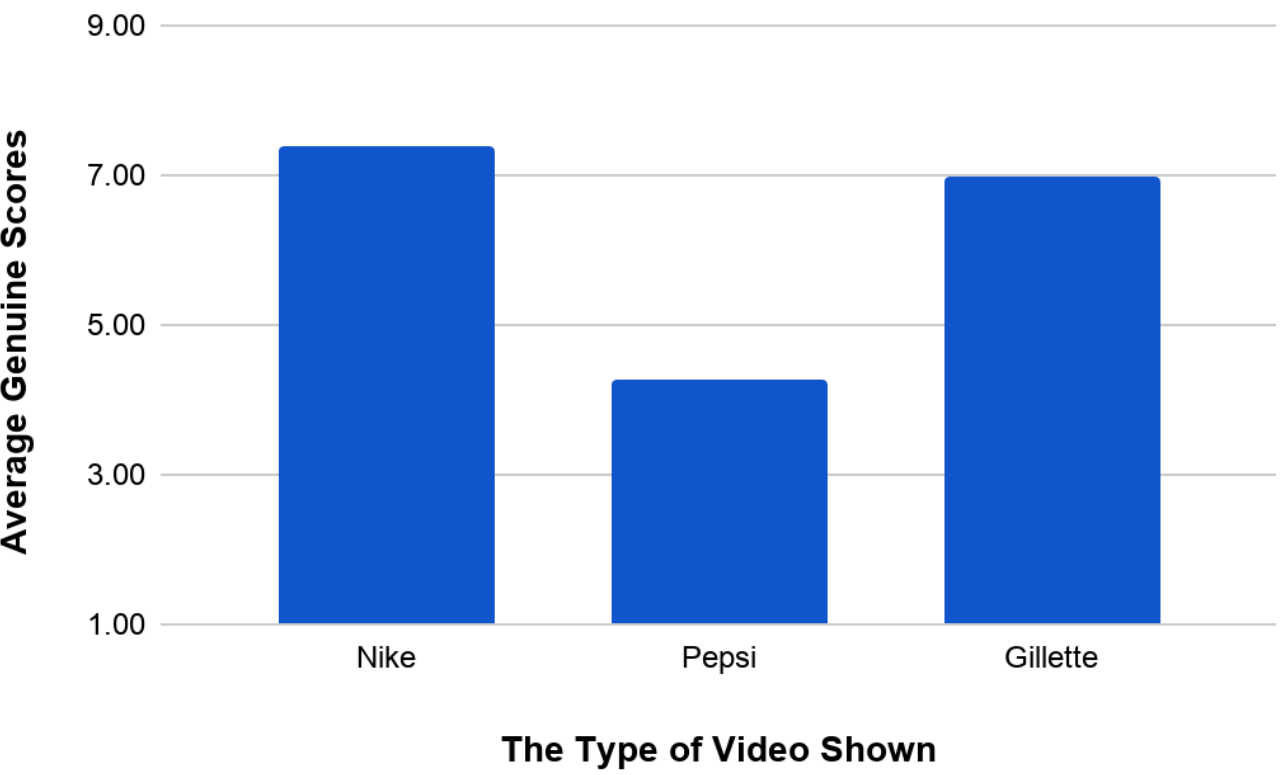

To test H1a and H1b (see Figure 1 above), a parallel mediation analysis was conducted treating marketing education as the predictor, persuasion knowledge and advertising appreciation as the two parallel mediators, the genuine scale as the outcome, and video and political orientation as covariates. 
Results (see Figure 3 below) showed no significant relationship between marketing education and persuasion knowledge $(p=.97)$, or between persuasion knowledge and reactions to the ad $(p=.32)$. Therefore, the data does not support H1a. Conversely, and as predicted by $\mathrm{H} 1 \mathrm{~b}$, marketing education displayed a significant, positive relationship with appreciation for advertising $(b=.14, \mathrm{SE}=.03, p<.001)$, and advertising appreciation in turn displayed a significant, positive relationship with reactions to the ad $(b=.43, \mathrm{SE}=.09, p<.001)$. More importantly, results suggested that the indirect effect of marketing education on reactions to the ad through advertising appreciation was significant $(a b=.06, \mathrm{SE}=.018,95 \% \mathrm{CI}[.03, .10])$, providing additional support for $\mathrm{H} 1 \mathrm{~b}$, meaning respondents with more marketing education displayed more favorable reactions to advocacy advertising due to enhanced appreciation towards advertising in general.

Figure 3. Mediation model illustrating the coefficient (standard error) for each effect.

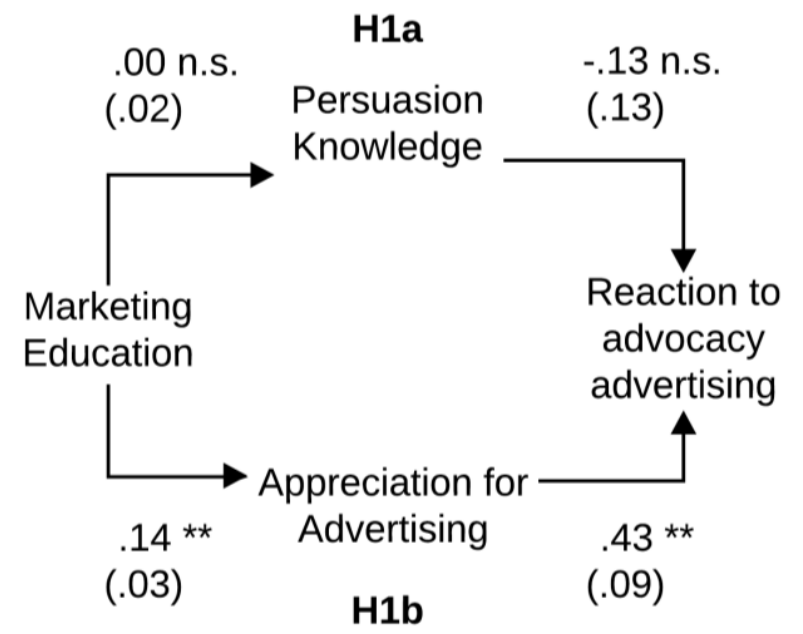

Note- $* * p<.001 ;$ n.s. $=$ not significant at $p>.10$

\section{General Discussion}

After conducting analyses for both qualitative and quantitative methods, the results support H1b. Both studies provided evidence that with a higher level of marketing education, one 
has a more favorable response to advocacy advertising due to a heightened appreciation for advertising in general. Conversely, H1a was not supported. Persuasion knowledge did not demonstrate any connection with one's level of marketing education or their reactions to the ad. Respondents still showed high levels of persuasion knowledge, but those scores did not have any relation with the other mediating factors. Lastly, these results illustrate that even among a sample that leaned liberal, students displayed a variety of opinions about advocacy advertising. Indeed, the effects in the model remained significant even when controlling for video and political orientation.

\section{Theoretical and Practical Implications}

These results broaden existing theories of motive attribution (Ellen et. al, 2006) by showing a new predictor, marketing education, and its impact on responses to advocacy advertising. These reactions generally illustrated that marketing education's effect on advocacy advertising was positive due to its influence on advertising appreciation. In particular, it further validates the work of many scholars who argue the importance of advertising literacy, in its ability to develop a sophisticated understanding of artistic styles (O’Donohoe \& Tynan, 1998) and in acknowledging its power to shape cultural meaning (Ritson \& Elliott. 1995). And, as mentioned before, the present study provides evidence that individuals with similar political views can display differing opinions about advocacy advertising. This is in stark contrast to existing theoretical accounts of political orientation as a central predictor of consumer response to advocacy advertising (Burgoon et. al, 1995; Haggard et. al, 2014; Haley, 1996).

From a practical stance, the current research helps provide new ways to measure advertising appreciation for not only college students, but for students at the elementary and high school levels as well. Additionally, it illustrates the importance of marketing education 
programs, and how they should continue to implement courses that highlight the cultural and artistic importance of advertising. By doing so, it can give greater insight to the world of marketing and advertising.

Contrary to what was previously believed, controversy around advocacy advertising extends beyond political differences. Thus, for marketing professionals themselves, they can use these findings to focus their segmentation and targeting efforts based on marketing education rather than just political differences. As a result, advocacy advertising messages will be able to reach the most impressionable target segments.

Especially amidst the COVID-19 pandemic, and as marketers try to have a social impact, it is important that they are rewarded by consumers for doing so. This will ensure marketers continue to address social issues, ideally in ways that advocate for positive social change. Therefore, enhancing consumers' appreciation for such attempts, through marketing education, can help society.

\section{Limitations and Future Directions}

One major limitation of the present research was that the quantitative study (Study 2) design was correlational, rather than casual. Thus, although the results suggest that marketing education predicts responses to advocacy advertising, a causal relationship cannot be inferred. Future research should use an experimental design to test whether this relationship is casual in nature, and not merely correlational.

Another limitation is that the sampling base for both studies was narrow, restricted entirely to undergraduate students at Portland State University. The small sample could be a reason for why there was a strong correlation between marketing education and advertising appreciation. With a larger sample size, it could potentially reveal different correlations among 
marketing education levels. Additionally, since this sample was mainly liberal, testing students from other colleges can help uncover different ways in which political ideology affects reactions to advocacy advertising. Future research should seek to replicate this pattern of effects among different populations of consumers.

Further, the interviews compared marketing majors with students who possibly were not at all experienced with persuasive tactics (e.g., business management, finance and public health majors). It may be more beneficial to interview students who are not marketing majors but still have a similar understanding of how persuasive tactics are used in the media (eg., English, film and psychology majors). One's background in psychology has been shown to increase persuasion knowledge and critical thinking as a whole (Friestad \& Wright, 1994), but further research should explore how responses are affected by film and English majors in relation to those studying marketing.

Finally, as theorized above, a relationship between marketing education and persuasion knowledge was expected (Boerman et. al, 2012; Dahlén, 2005; Henrie \& Taylor 2009; Russell, 2002; Xu \& Wyer Jr., 2010). Yet, no such effect was found. One possible explanation for this surprising discovery is a potential flaw of the Consumer Self-Confidence Scale (Bearden et. al, 2001) as the questions have led respondents to say they are aware of persuasion tactics in advertising, when in reality they may not be. It could prove useful to adopt another form of measurement that tests persuasion knowledge in a less conspicuous fashion. 


\section{Acknowledgements}

I would like to give very special thanks to my advisor, Brandon Reich, for guiding me through this process. With his helpful feedback and advice, he has motivated me to make this project the best it can be. And to all the students who participated in the interviews and took the time to complete the survey, your contribution is greatly appreciated. Overall, this has been a fantastic experience, and this thesis would not have been made possible without your support.

\section{References}

Babiak, K. \& Trendafilova, S. (2011). CSR and Environmental Responsibility: Motives and Pressures to Adopt Green Management Practices. Corporate Social Responsibility and Environmental Management, 18 (1), 11-24.

Bearden W. O., Hardesty D. M., \& Rose, R. L. (2001). Consumer Self Confidence: Refinements in Conceptualization and Measurement. Journal of Consumer Research, 28 (1), 121-134.

Boerman, S. C., van Reijmersdal, E. A., \& Neijens, P. C. (2012). Sponsorship Disclosure: Effects of Duration on Persuasion Knowledge and Brand Responses. Journal of Communication, 62 (6), 1047-1064.

Brucks, M., Armstrong, G. M., \& Goldberg, M. E. (1988). Children's Use of Cognitive Defenses against Television Advertising: A Cognitive Response Approach. Journal of Consumer Research, 14 (4), 471-482.

Buell, R. W. \& Norton, M. I. (2011). The Labor Illusion: How Operational Transparency Increases Perceived Value. Management Science, 57 (9), 1564-1579.

Buijzen, M. (2007). Reducing Children's Susceptibility to Commercials: Mechanisms of Factual and Evaluative Advertising Interventions. Media Psychology, 9 (2), 441-430.

Burgoon, M., Pfau, M., \& Birk, T.S. (1995). An Inoculation Theory Explanation for the Effects of Corporate Issue / Advocacy Advertising Campaigns. Communication Research, 22 (4), 485-505.

Cutler, B. D. \& Muehling, D. D. (1989). Advocacy Advertising and the Boundaries of Commercial Speech. Journal of Advertising, 18 (3), 40-50. 
Dahlén, M. (2005). The Medium as a Contextual Cue: Effects of Creative Media Choice. Journal of Advertising, 34 (3), 89-98.

Dreyfuss, E. (2019). Gillette's Ad Proves the Definition of A Good Man Has Changed. Wired. Retrieved from https://www.wired.com/story/gillette-we-believe-ad-men-backlash/.

Ellen, P. S., Webb, D. J., \& Mohr, L. A. (2006). Building Corporate Associations: Consumer Attributions for Corporate Social Responsibility Programs. Journal of the Academy of Marketing Science, 34 (2), 147-157.

Elliott, R. \& Wattanasuwan, K. (1998). Brands as Symbolic Resources for the Construction of Identity. International Journal of Advertising, 17 (2), 131-144.

Friestad, M. \& Wright, P. (1994). The Persuasion Knowledge Model: How People Cope with Persuasion Attempts. Journal of Consumer Research, 21 (1), 1-31.

Glaser, B. G. \& Strauss, A. L. (1967). The Discovery of Grounded Theory: Strategies for Qualitative Research. Chicago: Aldine Publishing Co.

Haggard, C. R., Yao, Q. J., \& Cai, L. (2014). Impact of Gender and Political Ideology on Chinese and U.S. College Student's Responses to Climate Change Advocacy Advertisements. Journal of International Business Research, 13 (2), 1-18.

Halberstadt, L. M. \& Schumacher C. (2019). Brands as Politicians- How Consumers Morally Judge Advocacy Advertising. School of Economics and Management, 1-89.

Haley, E. (1996). Exploring the Construct of Organization as Source: Consumers' Understandings of Organizational Sponsorship of Advocacy Advertising. Journal of Advertising, 25 (2), 19-35.

Henrie, K. M., \& Taylor, D. C. (2009). Use of persuasion knowledge by the Millennial Generation. Young Consumers: Insight and Ideas for Responsible Marketers, 10 (1), 71 81.

Hibbert, S., Smith, A., Davies, A., \& Ireland, I. (2007). Guilt Appeals: Persuasion Knowledge and Charitable Giving. Psychology and Marketing, 24 (8), 723-742.

Hoeffler, S. \& Keller, K. L. (2002). Building Brand Equity through Corporate Societal Marketing. Journal of Public Policy and Marketing, 21 (1), 78-89. 
Ignatius, A. (2013). Advertising Is an Art- and a Science. Harvard Business Review. Retrieved from https://hbr.org/2013/03/advertising-is-an-art-and-a-science.

Klein, J. \& Dawar, N. (2004). Corporate Social Responsibility and Consumers' Attributions and Brand Evaluations in a Product-Harm Crisis. International Journal of Research in Marketing, 21 (3), 203-217.

Lii, Y. S., Wu, K.W., \& Ding, M. C. (2013). Doing Good Does Good? Sustainable Marketing of CSR and Consumer Evaluations. Corporate Social Responsibility and Environmental Management, 20 (1), 15-28.

Malmelin, N. (2010). What is Advertising Literacy? Exploring the Dimensions of Advertising Literacy. Journal of Visual Literacy, 29 (2), 129-142.

Martínez, P. \& Rodríguez del Bosque, I. (2013). CSR and Customer Loyalty: The Roles of Trust, Customer Identification with the Company and Satisfaction. International Journal of Hospitality Management, 35, 89-99.

Mehta, A. (2000). Advertising Attitudes and Advertising Effectiveness. Journal of Advertising Research, 40 (3), 67-72.

Menon, S. \& Kahn, B. E. (2003). Corporate Sponsorships of Philanthropic Activities: When Do They Impact Perception of Sponsor Brand? Journal of Consumer Psychology, 13 (3), 316-327.

Morrison, M. (2015). No one trusts advertising or media (except Fox News). Ad Age. Retrieved from https://adage.com/article/media/marketers-media-trusts/298221.

Nava, M. \& Nava, O. (1990) Discriminating or Duped? Young people as Consumers of Advertising/Art. Magazine of Cultural Studies, 1, 15-21.

Nielsen (2017). Millennials on Millennials: A Look at Viewing Behavior, Distraction, and Social Media Stars. Insights. Retrieved from https://www.nielsen.com/us/en/insights/article/2017/millennials-on-millennials-a-look-atviewing-behavior-distraction-social-media-stars/.

O’Donohoe, S. \& Tynan, C. (1998). Beyond Sophistication: Dimensions of Advertising Literacy. International Journal of Advertising, 17 (4), 467-482. 
Ritson, M. \& Elliott, R. (1995). Advertising Literacy and the Social Significance of Cultural Meaning. In Flemming Hansen (Ed.): European Advances in Consumer Research, Provo UT: Association for Consumer Research, 2, 113-117.

Russell, C. A. (2002). Investigating the Effectiveness of Product Placements in Television Shows: The Role of Modality and Plot Connection Congruence on Brand Memory and Attitude. Journal of Consumer Research, 29 (3), 306-318.

Salmon, C. T., Reid, L. N., Pokrywczynski, J., \& Willett, R. W. (1985). The Effectiveness of Advocacy Advertising Relative to News Coverage. Communication Research, 12 (4), 546-567.

Schumann, D. W., Hathcote, J. M., \& West, S. (1991). Corporate Advertising in America: A review of published studies on use, measurement, and effectiveness. Journal of Advertising, 20 (3), 35-56.

Scott, L. M. (1994). The Bridge from Text to Mind: Adapting Reader-Response Theory to Consumer Research. Journal of Consumer Research, 21 (3), 461-480.

Shaw, H. J. (2007). The Role of CSR in Re-empowering Local Communities. Social Responsibility Journal, 3 (2), 11-21.

Skarmeas, D. \& Leonidou, C. N. (2013). When Consumers Doubt, Watch Out! The Role of CSR Skepticism. Journal of Business Research, 66 (10), 1831-1838.

Solon, O. (2017). Kendall Jenner's Pepsi Ad Criticized for Co-opting Protest Movements for Profit. The Guardian. Retrieved from https://www.theguardian.com/fashion/2017/apr/04/kendall-jenner-pepsi-ad-protest-blackLives-matter.

Stuebs, M. \& Sun, L. (2010). Business Reputation and Labor Efficiency, Productivity, and Cost. Journal of Business Ethics, 96 (2), 265-283.

Taylor, C. R. (2014). Corporate Social Responsibility and Advertising. International Journal of Advertising, 33 (1), 11-15.

Tutaj, K. \& van Reijmersdal, E. A. (2012). Effects of Online Advertising Format and Persuasion Knowledge on Audience Reactions. Journal of Marketing Communications. 18 (1), 5-18. 
Wagstaff, K. (2017). Pepsi finally unites America with its terrible Kendall Jenner ad. Mashable. Retrieved from https://mashable.com/2017/04/04/kendall-jenner-pepsi-ad-unitesamerica/.

Wang, A. \& Anderson, R. B. (2008). Corporate Social Responsibility Priming and Valence of CSR Framing on CSR Judgments. Public Relations Journal, 2 (1), 1-19.

Williams, P., \& Aaker, J.L. (2002). Can Mixed Emotions Peacefully Coexist? Journal of Consumer Research, 28 (4), 636-649.

Wright, P., Friestad, M., \& Boush, D.M. (2005). The Development of Marketplace Persuasion Knowledge in Children, Adolescents, and Young Adults. Journal of Public Policy \& Marketing, 24 (2), 222-233.

Xu, A.J. \& Wyer Jr., R.S. (2010). Puffery in Advertisements: The Effects of Media Context, Communication Norms, and Consumer Knowledge. Journal of Consumer Research, 37 (2), 329-343. 